\title{
EDUCATIONAL AND ORGANIZATIONAL PECULIARITIES OF PHARMACEUTICS DEVELOPMENT IN TURKISH REPUBLIC
}

\author{
K. Milenkaya, M. Zhbannikova \\ State public institution of Rostov region, Southern federal university. \\ Rostov-on-Don, Russian Federation \\ science-almanac@mail.ru
}

\begin{abstract}
More often historians began to address to various aspects of the medicine history, the regional peculiarities of its formation and development. However, there are practically no articles, dedicated to medicine development in Turkey, and particularly, concerning Turkish pharmaceutics in Russia. We considered some aspects of pharmaceutical branch formation in Turkish republic from 1923 to the present time. The role and tools of state support in creation of innovative pharmaceutical production, including the training of highly skilled Turkish specialists is defined. One comes to the conclusion that high import dependency of domestic market medications and medical goods appears to be unacceptable from the point of view of national security. The given problem was solved in a complex. Secondly, university reform was conducted, directed to secular education improvement, including pharmaceutical one. Lecturers, who did not prove scientific character of their work, were practically almost removed from Istanbul university, and new foreign lecturers were invited, mainly from Germany, whose works on pharmaceutics and related sciences passed scientific approbation. The history of basic professional pharmacological associations and societies are touched upon in the article. The challenges and activities of professional pharmaceutical associations are disclosed.

Key words: Turkish republic, pharmaceutical education, pharmacies in Turkey, Turkish pharmaceutical associations, pharmaceutical industry.
\end{abstract}

Historians more often began to address to various aspects of medicine history, regional peculiarities of studied problematic [16, p. 172-177]. The layer of works is dedicated to health service history of our country at various stages of its development, including, for instance, the Great Patriotic War, as especially significant period of USSR life. Thus, for instance, the medicine questions within the frames of local character, restricted by small territories, but rather particularly lighting these socially significant aspects are considered: "health service of Veshenskii region in the period of the Great Patriotic War executed the huge work. Despite on hard state of economics, military operations, destroyed medical institutions and lack of human resources, it could prevent mass diseases among population and development of epidemics" [11, p. 160]. Or, for instance, illuminating the role of party or soviet organs in USSR on medical personnel training "from the first days of war Rostov region took measures to improve and fortify health service system everywhere, amending the conditions and training of medical personnel: the number of polyclinics, ambulance stations, emergency departments and the number of beds in the hospitals, the net of healthy localities, feldsher-midwife stations and child care centers is reconstructed" [12, p. 193]. The works, which reveal, for instance, specific sides of medicine, rare touched by the researchers, but having the great significance for historical science development and appear to be synthesis of history and medicine, in the sphere of, for instance, psychiatry, emerged: "The participation of our doctors-experts in Nuremberg process speaks about high degree of domestic psychiatry merits recognition abroad". A lot of Nazi criminals, knowing, what was waiting for them, extremely skilful tried to stimulate madness" [15, p. 2060]. Or, for instance, comparisons of foreign and domestic health systems are interesting: "Great Britain 
innovations of social health service in the Russian empire were regarded as "democracy act", "radical changing in the system of self-regulation". F.F. Erisman wrote: "For people accustomed to absolute apathy to the public interests, as it is observed on the inhabitants of Russian cities, it should be strange, if they are told what colossal money is spent in the interests of social health by small and large English cities" [14, p. 15].

However, there are practically no articles dedicated to Turkish medicine in Russia. And information, concerning Turkish pharmaceutics, can be rarely seen, as this sphere not just simply takes one of the most significant steps in the world health service system. Considering such an important aspect of medicine history development, as pharmaceutics, one can notice the situation, which was formed in the Turkish society in the period of republic formation. The matter is that during the designated period the pharmaceutical education in Turkey was given by the only institution, namely Eczacı Mekteb-i Ali (Higher Pharmaceutical School). It was created on the basis of medical faculty of Istanbul university on $9^{\text {th }}$ of November 1908. Normative educational period comprised 3 years, and educational program was developed on the basis of Paris high pharmaceutical school [2, p. 194].

Initially, the pharmaceutical department was located along with the dental in a dilapidated wooden mansion Menemenli Mustafa Paşa (Menemenli Mustafa Pasha) and its conditions did not meet the goals and objectives of the educational institution, and then, thanks to the efforts of the doctor Server Khilmi Byuikaksoya at that period the head of the pharmaceutical school, these schools obtained the old building of gendarmery at the Beyazyt Square. After repairs and necessary rearrangements in 1926, the schools moved to a new building [2, p. 263]. On the second floor there was a pharmaceutical school, and in the basement and on the first floor - the dental one. For 33 years, Turkish pharmacists and dentists were educated in this three-story brick building. In 1933, in connection with the university reform, the pharmaceutical school was separated from the medical faculty and, based on the similarity of the educational program, was attached to the natural science faculty. Also in the course of the reform foreign professors, who significantly contributed to the given medicine direction, were invited to pharmaceutical school, as to the other university faculties (for instance, German professor K. Bodendorph, the author of "Short textbook on pharmaceutical chemistry" [4] and a row of other scientists), and the training term was increased to 4 years since 1938 [2, p. 270].

In 1944 Eczacı mektebi separated from the natuarl science faculty and again joined medical faculty and obtained the new title - Eczacı Okulu. It, as the former one, denotes "pharmaceutical school", but in contrast to Arabian "mektep" [13] word "okul" has Turkic origin that reflects gradual and firm work on replacement of numerous of Persian and Arabian borrowings in all spheres of state activity, social life and culture within the frames Kemalist reforms and shows that Turkish pharmaceutics developed in line, inseparable from the other spheres of education and health service.

In 1947 the decision about pharmaceutical school moving from the gendarmery building to the building of war medical school was accepted (the former mansion of Kechezhizade Fuad Pasha ) at Beiyazyt square [2, p. 277]. However, the mansion building continued about 12 years, and only in 1959 the school could move to the new building. Teaching staff of Istanbul university pharmaceutical school, supposing that the title "faculty" was more suitable for their structural subdivision, came forward with an initiative to discuss this question at the Soviet of medical faculty professors, and, on $4^{\text {th }}$ of Febtuary 1961 in the result of voting the renaming was approved. In 1960-s Istanbul university graduated about 60 dispensers that of course, could not satisfy demands of all country in specialists of this popular sphere. In connection with this, some private institutes resorted 
to the National education Ministry with a request to permit opening of high pharmaceutical schools, and in 19642 corresponding schools were created in Istanbul, and later they were opened in Ankara, Izmir and Eskisehir [2, p. 50].

Today more than 40 pharmaceutical educational institutions can be counted in Turkey [5], the largest of them are: pharmaceutical faculty of Istanbul university (1962), pharmaceutical faculty of Ankara university (1960), pharmaceutical faculty of Eskisehir university (1971). Since the establishment of High pharmaceutical school in 1908, its lecturers, despite on modest material and technical capabilities of educational institution, strived to introduce something new into pharmaceutical science, and the results of some researchers even were published abroad that speaks about their doubtless importance and topicality for the world science in whole.

The systematic approach to scientific researches and publications originates in the university reform of 1933 , the main point of which was concluded in university education improvement, and the role of leading university and the centre of scientific-research work of the country were fixed for Istanbul university [10, p. 60]. Invited foreign specialists, taught at that time at the pharmaceutical school, conducting researches and publishing their works, laid the foundation to the modern high level of education in the sphere of pharmaceutics and to prestige of this profession in Turkey: professor Khelbron contributed to the pharmacognosy development, professor $\mathrm{K}$. Bodendorf - to pharmaceutical chemistry, and professor L. Rozenataler and professor S.N. Brikson concerned with pharmaceutical technology (pharmaceutic medications, obtained in the result of crude drugs processing by physical way) [9].

There is an interesting fact that some dispensers took academic degrees, after the republic establishment, more often in Germany [2, p. 299]. One can conclude that this profession and knowledge sphere were popular, but nevertheless, insufficiently developed inside the country. Since 1949 the academic degree "Ph.D. of pharmaceutical studies" was entered in Turkey that once again confirms the significance, which this speciality begins to gain. Master's programme, with appointment to grade "Expert- dispenser", which precedes doctorate, was established in 1983. Currently, there are 7 universities, which prepare magisters and doctors in the pharmaceutics sphere in the country (Istanbul, Ankara, Hacettepe, Gazi, Anatolian and Aegean universities).

In 1988 the doctor Mustafa Nevzat Pysaka Award was established (1879-1868), played the significant role in the Turkish modern pharmaceutics development. He graduated from the military medical school in 1898, and received the qualification of "pharmacist-chemist" in 1902. Macedonian military hospital in Saloniki was his first place of work. Mustafa Nevzat took charge of laboratory in Istanbul medical school in 1911. He was commissioned to the medicine lecturer in 1915. He received the Medal of Honor from Grand Duke Franz Salvator Austrian for the work in the hospital of Red Cross during World War I. Professor Mustafa Nevzat also was a pioneer of many innovations in Turkish pharmaceutical industry. He was the first in Turkey, who began to practise injection ampoules, the first obtained prepared preparation for injections from insulinase powder, and also introduced such notion, as "quality control" for the Turkish medications [7]. This person broke through pharmaceutics sphere and significantly contributed to the Turkish medicine in general. The Mustafa Nevzat Pysaka Award is handed out once in two years for the outstanding achievements in pharmaceutical science.

Concerning the presence of pharmacies during the first years after Turkish republic formation, then as a rule, they were only in big cities (for instance, there were about 300 pharmacies in Istanbul in 1924), and in some ilya and ilche (units of the administrativeterritorial division of Turkey) there were no pharmacies at all. According to the inspector of 
health service ministry Ismail Khakky leshilyut: "in some regions there is practically no space in pharmacies, trade is poorly established, the shelves are almost empty and the financial state of the pharmacies is very deplorable" [8, p. 112].

In the same period, a fairly low production of medicines was noted, most were imported from abroad [2, p. 234]. Later the production of Turkish analogs began. The first medications were prepared in the pharmacies, and later were produced in small factory laboratories. Pharmacies Abdi Ibragim, Erdem Pertev, Beshir Kemal, Khasan Gergyulyu and Mustafa Nevzat stood at the sources of medicinal industry of Turkish republic. Professor Turkhan Baitop particularly considered this question in his book "The beginning of pharmaceutical industry in Turkey" [3, p. 236], dividing the given branch into 4 conventional periods:

1. Pharmaceutical period (1833-1928);

2. Laboratory period (1928-1954);

3. Factory period (from 1954 till the present time);

4. Production of curative-active pharmaceutical ingredients (from 1970 till the present time).

In order to protect the professional interests of Turkish pharmacists, professional associations were established (similar organizations existed during the time of the Ottoman Empire) [2, p. 306]. The Turkish Pharmaceutical Society was formed in June 1924, headed by Erdem Pertev Bay, which took the pharmacists to their ranks, from the number of former members of the Pharmacists State Ottoman Society, formed in 1909 in Istanbul. It was decided to accept only certified pharmacists into the Society, who appeared to be pharmacy owners in December 1926 at the Second general meeting. The Society was renamed into Istanbul society of pharmacists in 1928. The restriction that only pharmacy owners can be a member of the Society was lifted in 1928, which was again renamed into the Turkish Pharmaceutical Society, and the title Turkish Society of Pharmacy Owners completely fixed in 1954. The Turkish pharmacological union headed by Muskhin Somer was created in 1930. The union began to publish its own journal "Pharmacologist" from the 1 of February.

Since 1923 the journal "Young pharmacologist" was issued in Samsun, which was published by the Union of Anatolian Turkish pharmacists. The Turkish pharmacists association, published already 3 scientific journals was created in 1956 in Istanbul: Türk Eczacıları Mecmuası (1958-1963), Pharmacia (1964-1983), Mised (since 2001). This is incomplete list of Turkish professional societies and printed publications from 1923 till the present time, however, it greatly illustrates the development of pharmaceutics and editions, dedicated to the given sphere, in this country.

The emersion of the idea about professional holiday introduction is very interesting the thought about "Pharmacist day", with a goal to gather them from all the regions of the country for professional problems discussion, study and search of their solving was expressed in 1949 by Remzi Kogzhaer [6, p. 73]. But the decision about annually celebration of Pharmacist day was accepted only on $27^{\text {th }}$ of November 1958 at the III Congress of Turkish Pharmacist Union [1, p. 125]. Under the designation and determination of the date it was established that the first pharmaceutical class was opened by the doctor Bernard under the Istanbul medical school 14 of may 1839 during the time of sultan Makhmud II, that is why the 14 of May was oficially announced to be the day of pharmacist, definitely emphasized the growing role and significance of the given science. 


\section{Лumepamypa}

1. Baytop T. Türk Eczacılık Tarihi Araştırmaları. İstanbul, 2000.

2. Baytop T. Türk Eczacılık Tarihi. Kısaltılmış 2. Baskı, Hazırlayan: Mat A., İstanbul, 2001.

3. Baytop T. Türkiye'de İlaç Sanayiinin Başlangıcı, Acta Turcica Historiae Medicinae 3. 1996.

4. Bodendorf K. Kısa İspençiyari Kimya. İstanbul Üniversitesi Yayınevi, 1940.

5. Derszamani: URL: http://www.derszamani.net/eczacilik-fakultesi-tabanpuanlari.html (дата обращения 13.03.2017)

6. Kocaer R. Türkiye Eczacılığının Günü. Farmakolog 19(5), 1949.

7. Mustafa Nevzat PIsak:

URL: http://www.mn.com.tr/tr/about_us/p_mustafa_nevzat_pisak.aspx

8. Yeşilyurt İ.H. Cumhuriyet Eczacılığı, Farmakolog 15. 1945.

9. Академик. Режим URL:. http://universal_de_ru.academic.ru/874584/Galenik (дата обращения 13.03.2017)

10.Дадашев Т.П. Просвещение в Турции в новейшее время (1923-1960). М., 1972.

11. Жбанникова М.И. Здравоохранение Верхнего Дона в годы Великой Отечественной войны // Россия в мировых войнах Сборник научных статей. Ростов-на-Дону, 2015.

12. Жбанникова М.И., Колесниченко А. Под знаком Красного Креста (подготовка фрронтовых медсестер и сандружинниц в Ростовской области) // Первые шаги в науке. Сборник материалов II Межрегиональной научно-практической конференции студентов, магистрантов, аспирантов и молодых ученых. 2015.

13. Османо-турецкий словарь:

Режим URL:http://osmanli_turkcesi.enacademic.com/5933/mektep (дата обращения 13.03.2017)

14.Склярова Е.К. Викторианская урбанизация и роль общественного здравоохранения в развитии общества // Гуманитарные и социальные науки. 2013. № 6.

15. Склярова Е.К., Каледин 3.А., Малышко Л.В., Камалова О.Н. Особенности психиатрической помощи в СССР в годы Великой Отечественной войны // Научно-методический электронный журнал Концепт. 2016. Т. 15.

16. Склярова Е.К., Харламов Е.В., Камалова О.Н. Становление высшего фрармацевтического образования на Дону // Роль медицинских вузов в подготовке медицинских кадров: исторические аспекты. материалы Всероссийской научно-практической конференции, посвящённой открытию музея истории Иркутского государственного медицинского университета, в рамках празднования 355-летия города Иркутска. Иркутский государственный медицинский университет. 2016.

\section{References}

1. Baytop T. Türk Eczacılık Tarihi Araştırmaları. İstanbul, 2000.

2. Baytop T. Türk Eczacılık Tarihi. Kısaltılmış 2. Baskı, Hazırlayan: Mat A., İstanbul, 2001. 
3. Baytop T. Türkiye'de İlaç Sanayiinin Başlangıcı, Acta Turcica Historiae Medicinae 3. 1996.

4. Bodendorf K. Kısa İspençiyari Kimya. İstanbul Üniversitesi Yayınevi, 1940.

5. Derszamani: URL: http://www.derszamani.net/eczacilik-fakultesi-tabanpuanlari.html (resort date 13.03.2017)

6. Kocaer R. Türkiye Eczacılığının Günü. Farmakolog 19(5), 1949.

7. Mustafa Nevzat PIsak: URL: http://www.mn.com.tr/tr/about_us/p_mustafa_nevzat_pisak.aspx (resort date 15.03.2017)

8. Yeşilyurt I.H. Cumhuriyet Eczacılığı, Farmakolog 15. 1945.

9. Academic. Regime URL:. http://universal_de_ru.academic.ru/874584/Galenik (resort date 13.03.2017)

10. Dadashev T.P. Enlightenment in Turley in the newest time (1923-1960). M., 1972.

11.Zhbannikova M.I. Health service of the Upper Don during the Great Patriotic War // Russia in the world wars Collection of scientific articles. Rostov-on-Don, 2015.

12.Zhbannikova M.I., Kolesnichenko A. Under the Red Cross sign (training of front nurses and sanitary activists in Rostov region) // THE FIRST STEPS IN SCIENCE. Sourcebook of II Interregional scientific-practical students conference, magistrands, postgraduates and young scientists. 2015. Turkish dictionary:

Regime URL:http://osmanli_turkcesi.enacademic.com/5933/mektep (resort date 13.03.2017)

14. Sklyarova E.K. Victorian urbanization and the role of social health service in society development // Humanitarian and social sciences. 2013. No 6.

15. Sklyarova E.K., Kaledin Z.A., Malyshko L.V., Kamalova O.N. Peculiarities of psychiatric support in USSR in the Great Patriotic War years // The scientificmethods electronic journal Concept. 2016. Vol. 15.

16. Sklyarova E.K., Kharlamov E.V., Kamalova O.N. High pharmaceutical education formation on Don // The role of medical universities in medical personnel training: historical aspects. Materials of All-Russian theoretical and practical conference, dedicated to the history museum opening of Irkutsk state medical university, within the frames of 355 celebration of Irkutsk. Irkutsk state medical university. 2016. 